\title{
Seeing and Not Seeing Immigration
}

\author{
Immigrant Outreach in an Era of Proactive Policing
}

A growing body of research examines how government bureaucraciesparticularly those in new immigrant destinations-integrate or respond to immigrant residents. ${ }^{1}$ For example, Michael Jones-Correa coined the term bureaucratic incorporation to describe schools' and libraries' positive orientation toward immigrant residents in the suburbs of Washington, DC. ${ }^{2}$ Jones-Correa documented a number of examples where these institutions acted against their political interests by redistributing resources to help disadvantaged immigrants, at the risk of antagonizing more advantaged middle-class constituents. These examples of "bureaucratic incorporation" flew in the face of long-standing theories of political incorporation, which assume that minority groups must have political power before bureaucracies respond to their needs.

Since then, scholars have documented numerous examples of bureaucracies' positive orientation toward immigrant communities, as well as variation in bureaucrats' abilities or inclination to incorporate them. ${ }^{3}$ For example, recognizing that gaining immigrants' trust is important to police work, many police departments across the country have developed policies that are generally supportive of immigrants. ${ }^{4}$ Departments' "welcoming" practices may include recruiting bilingual officers, providing services in multiple languages, and engaging in symbolic or substantive immigrant outreach. ${ }^{5}$ For example, when police officers attend immigrant community events to send a message that immigrants are valued members of the community, the department engages in symbolic outreach. In contrast, when the department uses information from the immigrant community to change or formulate policies, these efforts are substantive. Both substantive and symbolic outreach represent conscious and 
deliberate attempts to respond to immigrants' needs and incorporate immigrants into the community.

Jamie Winders argues that to understand how bureaucracies respond to Latino immigrants, one must understand how bureaucrats see and do not see them. ${ }^{6}$ When immigrants are institutionally invisible, bureaucracies will not address their concerns. Thus bureaucratic incorporation depends on bureaucrats seeing immigrants as residents who are entitled to services and as legitimate constituents with a stake in the city's future.

This chapter examines how police see, and do not see, Latino immigrants in Nashville. The chapter documents the attempts of the Metropolitan Nashville Police Department (MNPD) to improve relations with the Latino immigrant community by both symbolic and substantive outreach efforts. These efforts, which appear to be sincere, acknowledge that the department sees Latino immigrants as residents who are entitled to police protection. However, Latino immigrants' institutional visibility is uneven. The department sees Latino immigrants, but Latino immigrants' concerns, particularly as they relate to the implications of "illegality," are either unnoticed or purposely ignored. Police administrators and police community liaisons extol the department's outreach efforts while ignoring or denying that police practices have immigration consequences. Patrol officers are only vaguely aware of the department's Latino immigrant outreach efforts, and they are similarly oblivious to Latino immigrants' concerns.

\section{THE EL PROTECTOR PROGRAM}

In 1999, an investigative journalist, Willie Stern, wrote a series of stories in an alternative weekly newspaper, the Nashville Scene, detailing how private security guards terrorized Latino residents at an apartment complex in Southeast Nashville called Ivy Wood. Guards beat, robbed, and harassed Latino residents whom they were hired to protect, betting that residents would not report the abuse for fear of deportation. ${ }^{7}$ The abuse was extreme-some guards seemed to enjoy forcing their way into apartments and dragging residents out of their cars.

A follow-up article detailed close relationships between the security firm and members of the MNPD. ${ }^{8}$ The firm employed forty police officers as private security guards during off-duty hours. While none of the guards who perpetrated the abuses were police officers, three officers allegedly knew about the abuses but did nothing. Moreover, an anonymous letter detailing the security firm's abuses was sent to the police department's internal affairs division, but the unit did not investigate until after the Nashville Scene broke the story. Federal and local authorities launched probes as well. The police department assigned one of its few Latino officers, Juan Borges, to work on the investigation's task force, citing Officer Borges's effectiveness at communicating with Latinos in the community. ${ }^{9}$ 
In the aftermath of the scandal, the security firm went out of business. The three police officers accused of knowing about the guards' violations were remanded to desk duty, pending further investigation. Two years later, the MNPD deputy police chief cleared the officers of all charges and the officers returned to active duty. ${ }^{10}$ No one from the security firm was ever punished.

In 2004, the MNPD launched a community-policing program called El Protector. Newly hired police chief Ronal Serpas announced the El Protector program at a "listening event," a public forum that invited Latino immigrants to a local high school to talk about policing. Modeled after successful community policing programs in California and Washington, the program aimed to improve the department's relationship with Latino residents. At the time, only 6 of the department's 1,300 officers were bilingual and few were Latino. The department picked a bilingual and bicultural officer who would focus only on outreach, rather than enforcement, to be El Protector.

Chief Serpas designated police veteran Juan Borges to run the program. In some ways, Borges's job as El Protector was a continuation of work he had already been doing. In 1998, Borges estimated that he was spending up to twenty hours a month helping officers communicate with Spanish-speaking residents. ${ }^{11}$ In 1999, Borges helped the department during its internal investigation of the Ivy Wood scandal. ${ }^{12}$ He was eager to take charge of the department's new community outreach program.

Borges was a charismatic detective who had been on the force since 1995. Born in Puerto Rico, Borges had moved to the United States on a college baseball scholarship. After college, he began a career in law enforcement. Officer Borges was not a big man, but he was a commanding presence. He walked in long strides, always with his shoulders back and his head held high. He had salt-and-pepper hair, a broad smile, and an accent that revealed his place of birth.

In the MNPD's 2004 annual report, the department devoted two pages to describing the new El Protector initiative. The report read:

Many in the Hispanic community are reaching out to Metro Police through a man known as "El Protector." He is an officer who speaks English and Spanish. His job is to bring information about the police department to Nashville's Hispanic community and to build trust between the department and the community. ... Officer Juan Borges, known as "El Protector," says it's the number one problem and that's why the police department is working to help Spanish speaking people find ways to communicate with police. ${ }^{13}$

In the report, Borges described his role as helping "improve the everyday lives of Hispanic people who live and work in Davidson County." During the program's first years, his work included setting up an El Protector Advisory Board and convincing a national cellular provider to donate dozens of cell phones for a 
Volunteer Translator Program. Officer Borges also established relationships with local businesses, organizations, and churches, speaking frequently at public events and meetings, as well as on Spanish-language radio. His talks addressed domestic violence, crime prevention, public safety, and DUI laws.

Despite Borges's efforts, questions about his temperament surfaced a few years into his tenure. While the police department continued to tout the El Protector program as proof of its exemplary ties to the Latino community, tensions simmered between El Protector and those he was purportedly protecting. ${ }^{14}$

\section{THE ATTACK OF EL PROTECTOR}

In 2006, debates over unauthorized immigrants' driving privileges were in full swing (see chapter 2). Undocumented residents lost eligibility for driver's licenses in 2004 and lost eligibility for driving certificates in 2006. In addition, a string of Hispanic businesses had been targeted for armed robberies that year, and the manager of a popular Mexican restaurant was beaten to death. ${ }^{15}$ Shortly thereafter, the Nashville Area Hispanic Chamber of Commerce announced that it was hosting an event to "discuss increasing criminal activity in our neighborhoods and the need for solutions and better avenues for communication."16

The day before the public meeting, business owners wrote a public letter to the police chief, requesting that the department adopt a policy banning immigrationrelated inquiries. The police chief had already gone on record saying that officers would not enforce immigration laws. In 2004 he told the paper, "With great respect and deference to our federal partners, we are not the INS. As long as I am chief of the Nashville police department, I'm going to be steadfastly against police being INS agents. It's just not our job. ${ }^{17}$ Much to business owners' disappointment, the chief declined to modify department policy, saying, "It would be improper for this department to implement a written policy that would preclude enforcement of any legislative act." ${ }^{\prime 18}$

The meeting took place in a large banquet hall in Southeast Nashville, and more than one hundred people attended. While the chief did not attend, Officer Borges attended with a number of other police officials. Business owners hoped that the meeting would facilitate conversation and communication, but the meeting quickly became contentious. Apparently Officer Borges refused to speak Spanish, despite repeated requests from assembled business owners for translation. ${ }^{19} \mathrm{~A} \mathrm{flu}-$ ent Spanish speaker, Borges said that navigating both languages was burdensome and unfair to English-speaking police officials at the meeting.

Esteban, who owns a number of Mexican grocery stores in Nashville, recalls that the meeting was acrimonious. He saw the comportment of department officials-from the chief's lack of attendance to Borges's refusal to speak Spanish-as a clear message that the department did not care about their concerns. 
"At the end, instead of having something positive, we left angrier, business owners against the police, police against business owners," Esteban said.

The relationship between El Protector and Latino residents deteriorated further when Officer Borges threw his hat into the ring in local politics. That fall, Borges ran as the Republican candidate against a Democratic incumbent for state representative of District 6o. Borges's entire platform was his opposition to illegal immigration. He pledged to end driver's licenses and state welfare benefits for unauthorized residents, even though they were eligible for neither. In addition, Officer Borges supported a city English-only language policy and advocated for allowing local police to enforce immigration laws. While his policy positions mirrored those of many Republicans running for state office in 2006, they were shocking when coming from the man who was charged with Hispanic community outreach.

Borges's about-face did not go unnoticed. On November 5, 2006, Telemundo ran a story called "The Attack of El Protector." ${ }^{20}$ The story opened with Borges doing his El Protector work in the community: a montage showed images of Latino businesses and residents in Southeast Nashville interspersed with Borges speaking, in uniform, at a community event. A broadcast journalist, Cristina Lodoño, narrated (in Spanish):

Nashville is one of the cities with the fastest growing Latino population in the last several years. More businesses, more work, and more customers, but it was the rise in crime against Latino victims that introduced the community to Juan Borges. This Puerto Rican officer was baptized as El Protector. His job was to be the principal translator and ally of the Latino community, to win their trust, but few could have imagined what he thinks about the undocumented. ${ }^{21}$

The story cut to an image of Borges and Lodoño sitting on white rocking chairs on the front porch of a small gray house. Borges wore blue jeans and a white longsleeved shirt. Speaking to Lodoño in Spanish, he said his experience as an officer had convinced him that undocumented residents harmed the city. "Sometimes they don't want to work," Borges said. "It's more easy to sell drugs." During the short segment, he railed against birthright citizenship and multiculturalism, saying, "When a person comes to a country illegally and has a baby, those children shouldn't be American citizens. When people come here, they have to integrate. They have to learn the language that is spoken here, and if they don't like those conditions, they should return to their country." ${ }^{22}$

George Ramirez, a local attorney and member of the El Protector Advisory Board, remembers being disgusted by Borges's statements. Ramirez, who is Mexican American and originally from Texas, saw Borges's candidacy and political platform as a great hypocrisy. As a Puerto Rican, Borges had the privilege of birthright citizenship, unlike many Latino newcomers to the city. Ramirez could also 
not understand why Borges, who did not speak English with the fluency of a native speaker, was attempting to score political points by supporting the English-only initiative. "I don't want to be mean, but he's the last one who should criticize other people for taking a longer time to learn the language," Ramirez said indignantly.

Frustrated by the turn of events, Ramirez met with Officer Borges and the police chief to express his concerns about the future of the El Protector program. He described the meetings with each of them:

I said, "I'm just going to be upfront with you, Juan, and I want you to hear it from me instead of hearing it from anyone else. I don't think you can go campaign on this anti-immigrant basis and still expect to be the bridge to the Hispanic community for the department. The two are just totally inconsistent. It doesn't make any sense." And basically, his response to me was, "These folks don't read the papers, and they don't know what I'm saying." In other words, he was saying these folks are all ignorant and that they didn't matter. I thought that just showed how out of touch he is, that he didn't respect the people that he supposedly is trying to build this bridge with. So I went to the chief and I said, "Look, let me make clear, Juan can say anything he wants on a campaign trail. I'm not here to demand he be removed as a police officer, that he be fired, I'm only saying this: you can't expect to bridge between the Hispanic community and the police department with the man who is going out on the campaign trail making all kinds of anti-immigrant statements. That's the wrong man to be El Protector."

The department acknowledged the controversy surrounding Borges's candidacy: "There are those in the Latino community that believe that [Borges's] effectiveness in the role of El Protector may be diminished because of some of his statements during the campaign," said MNPD spokesperson Don Aaron. ${ }^{23}$ Seeking to minimize Borges's role in the program that he helped launch, the department assigned Officer Ramon Iglesias to serve as an El Protector officer in an adjacent precinct. In 2008, Borges resigned his position and returned to patrol, and Officer Genaro Moreno, also Puerto Rican, took Borges's place in the South Precinct.

When I conducted my fieldwork, Officer Borges was back on patrol and no longer affiliated with the El Protector program. His successors were tight-lipped about the divergence between Borges's political statements and his professional responsibilities. One shrugged off the controversy, saying, "Juan's views had nothing to do with the program. We didn't discuss it during our duty hours. In fact, they never had a problem with how he was running the program, it was just his views."

\section{EL PROTECTOR 2.0}

Borges's tenure as the face of the El Protector program cast a long shadow on the department and its relations with Latino residents. When the Vera Institute of Justice (a research organization that focuses on access to justice) recognized the 
El Protector program as one of the nation's best practices with respect to policing immigrants shortly after Borges stepped down, some wondered if the department really deserved it. An immigration lawyer remarked upon the irony:

They won the award primarily because of the El Protector program. The idea of the program is excellent. The idea of reaching out to the community, having certain officers act as that bridge to the community. Has the program done some good things? Yes. But I don't think the people who gave that award really knew about all the [bad] things that were going on at the time.

While the anti-immigrant El Protector made Latino residents doubt the sincerity of the department's Hispanic outreach efforts, Officers Moreno and Iglesias worked hard to change their opinions. Officer Iglesias explained, "Our thing is community outreach. How are we gonna reach out to the community? How we gonna let them know that we're here to help them out? How are they gonna know that we as police officers are there to help them out?"

Officers set up booths at community events, shaking hands with countless residents and distributing El Protector trinkets to children. They spoke at local schools, churches, and community groups. They wrote articles for Spanish-language newspapers. They answered questions on the radio. They hosted numerous events including car seat safety inspections (where they inspected and replaced faulty car seats), community baby showers (where they distributed gifts to expectant mothers), community health fairs, annual festivals in different areas of town, and soccer tournaments. Indeed, when I rode with officers in Southeast Nashville, I regularly saw Officer Iglesias in the neighborhood distributing flyers and talking to people about upcoming events. Through these activities, officers tried to make personal connections with residents, community groups, and local businesses.

One summer weekday morning in 2009, I walked into the South Precinct roll call room. Three times a day, officers started their shifts in this large classroom to receive directions from their superiors before hitting the streets. This morning, however, the room was full of giggling teenagers rather than uniformed patrol officers. These teenagers, all of whom were Latino, were the first participants in the precinct's Hispanic Teen Police Academy. At the front of the room, a detective explained investigative work and showed students how to dust for fingerprints. Students were delighted as their prints, which had previously been invisible, appeared after a quick dusting. At the end of the week, students and their families attended a graduation ceremony in the precinct's multipurpose room. Students, holding certificates documenting their participation in the program, posed for pictures with family members and police officers. The precinct's commander, Mike Alexander, surveyed the scene with his arms folded across his chest and a look of satisfaction on his face. "When we have kids hugging our officers after a few days with them and asking if they come back, then we've won," he said. 
The police department described the El Protector program as a great success and pointed out the various awards and recognition that the program had received. In doing so, it privileged the assessment of researchers and police practitioners over that of the Latino community. For example, in a 2008 article published in the Tennessean, Chief Serpas insisted that immigrants were not afraid of the police and were reporting crime: "To the concern that there is some gap occurring between crime reporting of Hispanics and fear of the police department, I think we have two things to point to. Our program has been identified as a best practice in the nation, and we're seeing more crime reports from Hispanic surnames coming through the police department." ${ }^{24}$ However, if department representatives truly believed this, it was only because they were choosing to deliberately ignore the many people who told them otherwise.

\section{LOST IN TRANSLATION}

It is not unusual for police and community residents to fail to see eye to eye. Police tend to feel misunderstood and unappreciated by the public. ${ }^{25}$ Publicly embattled, police agencies filter and transform all the information they receive to suit their own needs, creating and reifying the social world in which they do their work. ${ }^{26}$

Officers and Latino residents have different ways of seeing and understanding policing in Southeast Nashville. The police department cares about Latino outreach, but only in the context of the activities and mission of the El Protector program. Latino residents appreciate that the El Protector program exists, but they see the program as symbolic. Police administrators and El Protector officers respond to the concerns of Latino immigrants in principle, but they have no interest in changing their practices. Most Latino residents come into contact with patrol officers who do not see establishing positive relationships with the precinct's diverse communities as an integral part of their work. Instead, patrol officers are socialized to pursue proactive policing and chase stats, policing tactics that make Latino residents feel alienated and surveilled. Even when Latino immigrants and police representatives make legitimate and earnest attempts to communicate with one another, their respective messages are lost in translation.

This became clear to me at a "Hispanic Community Business Meeting" that took place in a dining room at Los Arcos, a large Mexican restaurant on Nolensville Drive. The South Precinct invited Latino business owners to a meeting to discuss property crime and share the department's community policing initiatives. Officers Iglesias and Moreno (of El Protector), the precinct commander, and thirteen Latino community members (who I assumed were business owners) attended the meeting.

As the meeting began, Officer Moreno thanked us for coming, switching between English and Spanish: "Es muy importante que están aquí [It's very important 
that you are here] so we'll know if we're doing a good job or not." He launched into a short presentation about the El Protector Program and its many efforts to reach out to the community. As he talked, a slideshow projecting images of police officers interacting with Latino children appeared on a screen beside him. We saw children holding prizes at a festival, children sitting raptly in a classroom watching an officer give them a lesson, and children crawling in and out of police helicopters and armored vehicles.

The slideshow ended, and the commander spoke next, making an emotional plea about the department's commitment to serving the businesses, patrons, and workers of those in attendance. "We want to know what we can do to help you," the commander said. "We want to talk more and trust each other more. We're begging for your input.”

At the commander's invitation, attendees at the meeting took turns speaking. A petite woman, Teresa, stood up and took the floor, saying, "The reason why I'm here is that I have a store, a Latino grocery store on Murfreesboro Road, and every day there's police on the street stopping cars. It's too much. Too many police officers, too many. It hurts our business. Everybody's walking now because they're afraid. Then lots of times they park in our parking lot and block the entrance. When the police are stopped outside, everyone freezes. And I think, what's going on? No one's going in or going out. And it's not just one, it's more than one. It's like a party. I understand if they're working, but they're talking about something else, like TV. And I'd like to ask them, 'Hello, Officer, can you move your car a little bit? Or, how long are you going to be here?' But they're just rude!"

As she spoke, other business owners nodded in agreement. The police commander listened with his head cocked and nodded sympathetically at her. He explained that officers could not control where drivers decided to pull over. Some drivers might choose to pull into her parking lot out of comfort or convenience. He addressed Teresa's concerns about officers' comportment. "They shouldn't be rude," he said, "You can make a courtesy complaint about that."

While the commander might have thought that he adequately addressed Teresa's concerns, he did not engage with her biggest complaint. Teresa objected to the department's widespread deployment of vehicle stops. She described streets oversaturated with police activity. She explained how traffic enforcement produced immobility, curtailing residents' freedom of movement and locking them in place.

As I showed in the last chapter, these effects are consistent with the department's priorities. The department believes that aggressive traffic enforcement pushes crime to other zones by sending a message that police are hypervigilant. Thus, while the commander may have heard her concerns, he likely felt the department's mission superseded her grievances.

The next person to stand up and speak was Ricardo Chairez, a Mexican immigrant and business owner who had arrived in Nashville in 1987. Clearing his throat, 
he announced that he was going to share someone else's experiences. He gestured to the woman standing next to him. She was a waitress at Los Arcos and was taking a break from busing tables while Ricardo recounted her story. He began, "Okay, her story is very clear. Adela works here, she gets out late. She was on her way out of the parking lot one night and an officer followed her for three or four miles: all the way down Nolensville Road, all the way down Harding Place, until he stopped her at Haywood Lane. Eventually he pulls her over. He said the reason he stopped her was she didn't use her turn signal. But she says, 'How could that be? If I know that the police is following me, why would I make that mistake?'”

Adela nodded, confirming the details of his account. Ricardo continued, telling us that after Adela was stopped, multiple police cars arrived on the scene. Officers asked to search Adela's car and purse and commented on the large sum of cash she had in her wallet. Ricardo seemed particularly disgusted by this intrusion, stating that he had $\$ 400$ in his pocket and asking, rhetorically, if that made him a criminal. Ricardo conceded that the stop had ended fairly; Adela was given a citation for driving without a license and was permitted to leave. However, he objected to the police officer's tactics, tailing Adela for miles until he spotted an alleged violation. He also wondered why so many officers had arrived on the scene for a simple traffic infraction.

The commander responded to Ricardo's story, saying he could not comment on the traffic stop without more detail but that the department would investigate any allegations of wrongdoing if there were concerns. He explained how he directed patrol officers:

Wherever we have crime occur, that's where we're going to send our people. This Saturday night, just one example, we got hit with a personal robbery spree, okay? Armed suspects were going up to people and robbing them. At the Maple Crest Apartments, four personal robberies within an hour Saturday night. They drove right over to the Sunrise Apartments, four personal robberies there. Between those locations, just this Saturday night, I had eight people robbed by armed suspects. Therefore, I'm going to put the police there. It's not just me sending folks out and saying, "Hey, go do whatever you think you can do best." No. We've got problems here, we've got armed suspects that are still on the loose that we still haven't caught, and we've got to find them. I want you to know that's my reasoning behind where we deploy our resources.

Ricardo shook his head and held up his hand, unsatisfied with the commander's reply. Ricardo insisted there was a difference between what the commander was saying and what the police officer was doing by stopping Adela. He argued that the department's standing in the community was in jeopardy:

You work so hard, Commander, and Officer Moreno. I've worked with the department over ten years. I helped put the El Protector program together. I taught at the police academy. So they've been reaching out to the Hispanic community for a long 
time. I appreciate that very much, and I appreciate all the hard work that you do. That's a lot of work. I know what it is to put a program like that together. But all that work that you're doing will fail if you do not get to your officers and make them understand that they've got to stop profiling.

Ricardo's statement gets at the heart of the tension between law enforcement agencies' dual missions of service provision and social regulation. Like Teresa, Ricardo asserts that the department's aggressive traffic enforcement undermines its social standing in the Latino immigrant community.

Of course, as I showed in the last chapter, officers had several ways to rationalize an officer's behavior as a "good stop." Having identified an alleged violation, the officer was free to pull Adela over. Since the stop was legally acceptable, and in line with the department's priorities, it could not be unfair. Coming to the officer's defense, Officer Moreno explained officers' numerous rationales for making vehicle stops. Speaking in Spanish, he said:

Sometimes people drive and they think they're in their own country. One has to forget those ways and learn how to drive here. Okay? Tennessee state law says that when a person drives and their taillight is broken, that's a traffic stop. If they don't have their seat belt on, it's a traffic stop. If your headlights aren't on and it's raining and you're running your windshield wipers, that's a traffic stop. One day I stopped six Latinos, and I'm Latino! I'm not looking for people, I'll stop whomever. But that day they were all Latino. I asked the first guy I stopped, "Why did I stop you?" He said, "I don't know, because I'm Latino?” "No, look, you didn't have your seat belt on." Then I asked, "Where's your driver's license? Your ID? Your passport?” Nothing. And that's why we take people downtown! I don't know who this person is, he could be whoever. He could have committed a crime in California and come over here. I don't know who he is, so I have to take him downtown. I go to the consulate and I always tell people to have their ID so that officers can know exactly who you are. Show your matrícula. Show your passport. Show whatever documents. Show this one and that one, and that's how an officer will know. They'll just give you a fine, but you have to go and pay it.

Officer Moreno looked at Adela and put her on the spot, his voice booming. "What happened to you?" he asked her, rhetorically. She did not respond, and he continued, "They gave you a fine and you left, right?"

Adela nodded slowly.

"Did Immigration take you?" Officer Moreno asked, accusingly. He was no longer speaking to Adela and was addressing the group instead.

"No? Okay. What happened? You paid a fine. You paid a fine, and Immigration wasn't there," insisted Officer Moreno.

He continued, exasperated, "I mean, there's all these rumors about court, and they say not to go because Immigration is there, and the community is hurting itself with the rumors. You have to do your part too, that's the problem here. We can tell people and tell people to go to court, but you have to help too." 
As a Latino officer who ran a Hispanic community outreach program, Officer Moreno should have been the most receptive to Adela's concerns. Still, he saw Adela's experience through the gaze of a patrol cop. To Officer Moreno, pulling over vehicles for minor violations was perfectly legitimate. He acknowledged that Latino motorists thought he was profiling them, but he dismissed the possibility given his own ethnic background. As he understood it, the problem was not that officers made stops - the problem was that some Latino residents did not conform to legal requirements. He explained his frustration that some residents did not present appropriate identification. He blamed Latino residents' fear of the criminal justice system on rumors, rather than on their vulnerability to arrest and deportation. He suggested that their fears were misplaced, emphasizing that, at least in Adela's case, "Immigration wasn't there."

\section{POLICE NOT SEEING IMMIGRATION ENFORCEMENT}

Police administrators seemed both frustrated and puzzled at any suggestion that the organization contributed to deportations through their power to arrest. They emphasized that immigration enforcement was a federal responsibility and that the county's implementation of the $287(\mathrm{~g})$ program had nothing to do with the MNPD. They asserted that the Davidson County Sheriff's Office was a separate and autonomous agency. According to the MNPD, policing had not changed at all. Police administrators sidestepped concerns about immigration enforcement and instead drew attention to their efforts to improve police relations with the Latino community. The El Protector program was used as a shield, to be deployed against any suggestion that the department neglected the concerns of undocumented Latino residents. Indeed, officials used expansive rhetoric to assert their commitment to serving all Nashville residents.

Indeed, the police chief consistently emphasized that the department did not enforce immigration laws and that he would not support such an effort. He categorically rejected any suggestion that police arrests were equivalent to immigration enforcement. Instead, he emphasized the sheriff's role in enforcement and argued that deportation was a result of being out of status, not a result of police practices:

I did get agitated because advocates in the media were propositioning that because the sheriff was deporting people, police officers are destroying families. And I got really agitated about that and say, whoa, wait a minute, you are not going to successfully convince our officers that they are somehow or another destroying families when they themselves are not the one that are here in the condition that's here.... They're not the ones who were here without the proper status. They were doing their job. They were expected to do their job. They're not expected to ignore things that they couldn't ignore. I think they thought, let's attack the cops and make them feel 
guilty about doing this, and maybe they'll leave it alone. And I said that's not right.

I can't sit by and let you try to have my officers feel guilty. It's not of their making.

Of course, the chief's assertions were disingenuous in light of his early support of the $287(\mathrm{~g})$ program. When Sheriff Hall announced that his agency would pursue immigration enforcement authority, the MNPD issued a joint press release touting the program's capacity to protect residents. The press release conveyed that the $287 \mathrm{~g}$ ) program had the endorsement of Davidson County's two top law enforcement officials. After that early announcement, the police chief neither publicly supported nor opposed $287(\mathrm{~g})$. The department insisted that immigration inquiries should be directed to the sheriff's office because $287(\mathrm{~g})$ was the sheriff's program.

The commander of South Precinct explained to me in an interview that the department had an obligation to "serve everyone regardless of where they may be from, in the best way we possibly can." He also said that the department never formally addressed the $287(\mathrm{~g})$ program with officers because they did not believe that the $287(\mathrm{~g})$ program affected their practices:

It's entirely the sheriff's idea, and he implemented it. It has not changed anything as far as how we conduct our business, because we're completely separate from that. That's why our officers have no immigration enforcement authority-so immigration status cannot enter our officers' minds whatsoever in terms of if we do something or if we don't. It can't. We have no authority to do it.

Similarly, at an event hosted by Mexican consulate, I watched Officer Moreno pace the stage with a mic in his hand, telling corny jokes and exhorting attendees to wear seat belts and never drink and drive. He also answered questions that reflected attendees' concerns about immigration enforcement. Officer Moreno tried to assuage residents' concerns, telling them, "We don't care about that stuff. We're not Immigration. . . . That immigration enforcement program is in the jail. We don't run the jail, but police don't care about immigration."

My own discussions with officers indicated that some were in the dark about the $287(\mathrm{~g})$ program's consequences and priorities. Officers saw arrests as an ordinary and mundane feature of policing and were largely blind to its possible consequences. Some had vague knowledge that the $287(\mathrm{~g})$ program existed, but some believed that the program targeted only serious offenders. Even Officer Moreno, who in his job as El Protector should have known how the program worked, occasionally insisted that arrests did not result in deportation.

There are two possible explanations for officers' misunderstanding of the program. First, a police officer with years of experience would inevitably arrest some repeat offenders. Some officers saw jail as a revolving door. They were not immigration experts. It might not occur to them that one's immigration status would affect how one was processed through the jail, particularly when a driver's license 
arrest would not have resulted in deportation before the implementation of the $287(\mathrm{~g})$ program. Second, deportation is not necessarily a discrete event: for some it is a process. Thus officers might have assumed that because some immigrants got bailed out of jail they were no longer in deportation proceedings. This was an erroneous assumption. It is, of course, also possible that police knew about the effects of their practices but willfully cultivated ignorance because they were unconcerned.

\section{WHO WILL PROTECT US FROM THE POLICE?}

In Spanish, the term El Protector does not simply mean "one who protects," as it does in English. In Spanish, the term conjures up an image of a kick-ass vigilante superhero-a caped crusader who keeps the public safe from harm or injury. While the El Protector program intervened to help Latino residents manage some interactions with the department (such as reporting offenses, filing reports, or speaking to detectives), these officers could not change the culture of the department. Sometimes Latino residents indicated that they needed protection from the police (see chapter 6).

Thus the El Protector program was criticized because some found its title a misnomer. The program facilitated the flow of information, but it could not protect Latino residents. Lydia, a Mexican immigrant from Jalisco who worked for an immigrants' rights organization, explained:

This is why we're so mad about the Protector program. This is where the rage comes from. I'm not against the El Protector program. Their mission is good. They educate about traffic laws, seat belt laws, car seat laws, that's good. But I'm very against the fact that they say they don't do immigration enforcement. Look, they always say you should call the police. Nothing will happen to you. We are not Immigration. But the police are very ignorant about immigration laws.

As a result, a number of immigrant advocates said they felt conflicted about recommending that Latinos call the police because they could not be sure that residents who called the police would not wind up arrested themselves. Mario, who worked for a nonprofit organization that helped Latino immigrants secure loans to buy houses, explained:

Look, people don't want to report crimes to the police. I understand police campaigns like the El Protector program. They're saying that they're not from Immigration, they're not from Immigration, but we all know that if you call the police you place your future in their hands, because it's the officer that's going to decide what to do with you. ... I've seen cases like that. I know of cases like that, some more confusing than others, but with the same conclusion. "I called to report a crime and it ended badly." They say it doesn't happen, but I know it does. I know it does. 


\section{CAN I GIVE YOU A HUG?}

Like Lydia and Mario, I was acutely aware that interactions between Latino immigrants and the police could result in arrest and that arrests came with particularly severe penalties for undocumented residents. When Latino immigrants responded to police officers with fear or apprehension, I thought their concerns might be related to concerns about immigration status. As a migration scholar, I read interactions between Latino immigrants and the police through an immigration lens. In contrast, immigration status appeared to be institutionally invisible to most officers. Officers acknowledged that their presence made Nashville residents nervous (indeed, they griped that traffic slowed perceptibly when residents saw police cars), but they never linked this anxiety to concerns about immigration status.

One evening I was riding with Officer Bard, a white twenty-six-year-old officer. Over the radio, the dispatcher alerted us to an emergency in progress: a young girl had called 911 to report that her dad had a knife and was threatening her mom. We hurried to a large apartment complex, going fifteen to twenty miles over the speed limit, with lights and sirens blaring. We located the right building and arrived with two other patrol cars. Three officers bounded up the stairs and I followed closely behind them. They identified the right door.

Officer Bard pounded on the door with the side of his fist four times. "Policeopen up," he called loudly. He pounded again.

Moments later, a girl, whom I'll call Maricela, opened the door. Tears stained her face. Her mother stood five feet behind her, hugging Maricela's younger sister, who was also crying. Maricela opened the door wide and stepped back, retreating to her mother's embrace and whimpering.

Bard asked if we could come in and Maricela nodded, opening the door wider and taking a step back. Bard told them we were responding to a call about someone with a knife and asked if everyone was okay. Maricela's mother looked at us blankly. I immediately stepped forward and asked if she spoke Spanish. When she said that she did, I told her that I was not a police officer but I was accompanying them for the evening. She nodded, and I looked at Bard for instructions.

Bard told me to ask if anybody had a knife. Maricela's mom looked confused and shook her head no.

"What happened?" I asked.

She said that she had had a "disagreement" with her husband but failed to offer more details. Bard asked me to ask her if the officers could take a quick look around the apartment to make sure he was gone, and she nodded. The two other officers stepped into a bedroom and bathroom but returned quickly, saying it was "clear." One officer stood close by and watched the scene unfold, while the other officer stepped into the hallway. 
Bard asked if her husband had hurt her. "Are you hurt?" he asked, peering at her intently and looking her over. I knew he was looking for visible marks that she had been hit or assaulted because this would require the mandatory arrest of her assailant. She shook her head and said that she was fine. When I asked if her husband had hit her, she avoided the question.

We asked for her name and her husband's name and she gave us both. A minute later we heard an officer yell in the hall and Bard stepped out to see what was happening. "We've got him," an officer yelled. They returned to the apartment followed by a man wearing worn jeans, a faded sweatshirt, and sneakers. He had bronzed skin, short dark brown hair, and the hands of someone who had done years of hard labor.

"Is this him?" Bard asked.

I asked Maricela's mom if this was her husband and she said he was. As she verified this, she stared at the floor. An officer led Maricela's dad across the apartment, about ten feet away from his wife and daughters, and told him not to move. The officers distributed themselves in the room strategically: one officer standing next to Maricela's dad, one officer standing next to Maricela's mom, and one officer standing between them.

Maricela's mom ushered her daughters toward her, and I resumed trying to piece together what had happened. By now, they had stopped crying, although the girls-and their mother-looked distressed. I told Maricela's mom that we had been called about a domestic assault. She stared at me with wide eyes but didn't respond.

"Can you tell us what happened?" Bard asked Maricela.

Maricela, responding very timidly, said that her parents had gotten into a fight and she had been scared. They had gotten in fights before, and she did not want anything to happen to her mother. Her dad had not brandished a knife, but Maricela had thought he was going to.

I started asking if that was why she had called the police, but the look of alarm on her face stopped me. I paused. She looked at me and pleaded, "Don't tell them I called. Don't tell them I called." By the time Maricela's words registered with me, she was looking toward her dad. He looked scared, and he seemed to be shaking his head no, almost imperceptibly. He took a step toward his daughter, and an officer barked at him, telling him not to move.

Bard and the officers conferred. If Maricela's mom was not willing to tell them what had happened, there was nothing they could do. There was no evidence that she or her children had been assaulted, and there were no previous incidents of assault. They decided that the best thing they could do was "cool down" the situation by asking Maricela's father to leave for the night, even though they could not legally obligate him to do so. 
"We're going to make him leave, okay?" Bard asked Maricela and her mom. They nodded.

The officers turned their attention to her father. "You have to go," an officer told him. Maricela's father looked at the officer and didn't move. "You have to stay somewhere else," the officer said more loudly. "Get some stuff and let's go."

Tentatively, Maricela's dad shuffled toward the bedroom. An officer followed him. Thirty seconds later they reemerged, and Maricela's dad was carrying a plastic grocery bag with a few pieces of clothes in it.

"He's going to leave, okay?" Officer Bard said to Maricela and her mother. Maricela's mom whispered something in Maricela's ear. Maricela looked up at her and sighed.

"If my dad can give us money," she said quietly.

Bard looked at her and held up his hands, as if to indicate that he could not enforce this kind of request. She walked toward her dad.

"Can you give us some money, papi?" her voice wavered.

He turned his empty hands palm up.

"I don't have any, mijita," he told her, using a diminutive Spanish term of endearment referring to Maricela as his daughter.

"Please, papi," she said, imploringly, "please."

"I don't have any."

She took a step back, and an officer waved Maricela's dad to the hallway. They began to ask him more questions, including if he had been drinking.

I turned my attention back to Maricela's mom. Officer Bard explained that the police were not going to press charges but that she could go downtown to file an order of protection against her husband if she was worried about her safety. "Would you like to file an order of protection?" he asked.

Maricela was nodding her head emphatically, even before we translated for her mother. I translated the officer's statement and Maricela's mom looked at the officer, then at Maricela. She hesitated. Maricela encouraged her with "Yes, Mom."

Officer Bard said again that she could file an order of protection and that he could help her. I translated. Maricela's mom stood up straighter and nodded affirmatively. She would file the order.

Bard explained that we would drive her downtown where she could testify in front of a judge, and then her husband would not be able to bother her anymore. Bard told us to wait a second and went to see what was happening outside.

When he left the room, Maricela's mom started pacing around the kitchen. Maricela ran her hands through her hair.

"You ok?" I asked her.

She looked at me, shame flitting across her face, and said, almost in a whisper, "I'm so tired of it. Sometimes I wish I weren't alive anymore. I just want to die." 
I was at a loss for words. At that moment, Bard returned. Maricela's mom was still pacing. Bard asked if we were ready to go, but Maricela's mom had changed her mind, saying she'd rather stay home. "No, Mom, let's go," Maricela told her.

Another officer peeked in from the hallway and said he was taking off. Bard told him that that was fine and brought his attention back to Maricela's mom. Officer Bard told her that it was her decision but that if she wanted we would all go downtown together and she could file an order of protection. He looked at her expectantly. She did not respond. Bard told her that she did not have to decide now and that she could always go downtown and file it herself. I told her in Spanish, and she nodded that she understood.

"I'll go another time," she said.

"Are you sure?" I answered. "We can take you now. Do you have a way to get there?"

Maricela's mom did not respond.

Officer Bard asked her again, offering to take her downtown, but she told us that she would go herself. Bard nodded and told her that they had instructed her husband to stay away for the evening but that they could not really enforce the request without an order of protection. I told her in Spanish and she said, "Okay."

Bard asked if she felt safe in their apartment. Did she want to go to a shelter with her daughters? She said she'd rather stay in their home, and Bard nodded. Bard began filling out an incident report on a clipboard. He asked Maricela to confirm her name, her parents' names, and their address.

Officer Kerns stepped inside and asked if everything was okay. Bard responded that we were wrapping up. Bard started chatting with Kerns, and I turned my attention back to Maricela, wondering if I could say anything that would offer relief.

"Can I give you a hug?" I asked her.

She nodded.

I wrapped her in my arms. I wanted to tell her that things would get better or that it would be okay, but these words rang hollow. I wanted to tell her something that was true. "You're very brave," I told her, staring into her eyes.

Bard and the other officer were still chatting. Bard finished the incident report and tore it off the pad, ready to give it to Maricela's mom. He handed it to her, gave her the phone number to the department's domestic violence division, and told her that she could always call for additional help. She thanked us and we left. We went back to the two patrol cars.

Officers dislike responding to domestic violence calls. Responding to them can be dangerous for officers and victims. Often there is no easy resolution. Victims may be reluctant to cooperate with officers or file for an order of protection. Moreover, incidents of alleged domestic violence require that officers fill out additional paperwork. 
"DV calls are the worst," said Kerns. He looked at his watch and let out a low whistle.

"What?" I asked.

"How long do you think that took?" he asked me.

"I dunno. Twenty minutes?"

He shook his head. "An hour and a half."

"Really?" I answered.

"An hour and a half and we didn't do nothing," responded Kerns.

"Let's get the fuck out of here," said Bard.

I got into the car with Bard, and Kerns drove off.

This stop stayed with me. I remember the look of terror on Maricela's mom's face as she opened the door and saw uniformed officers. I remember Maricela's vacant and expressionless eyes, and her shaky confession that she sometimes wished for death. Maricela's revelation left me in an ethical quandary. I did not want to share her family's situation, but I worried that she might hurt herself. The next morning, I called a friend who worked in the elementary school district as a social worker. I explained what had happened and asked if she might check on Maricela's well-being. A few days later, I learned that school social workers had spoken with Maricela. She was stressed out but relieved to unburden herself. I do not know what happened to her or her family.

\section{YOU'RE NOT IN TROUBLE}

This was not the only time I saw possible concerns about immigration when officers did not. When Officer Hansen and I arrived at a local park after being called about a disturbance at a birthday party one Saturday afternoon, we thought we might be breaking up a fight or an argument between adults. We arrived to find a peaceful and happy child's birthday party. I thought we had arrived at the wrong park, but a white woman wearing a striped shirt walked toward us and flagged us down. She held a lit cigarette and intermittently puffed as she recounted her complaint. A little boy who had not been invited to the party had arrived and caused trouble. He had thrown sticks and hit her son, the birthday boy.

While I kept an impassive expression on my face, I wanted to scoff at her. Couldn't she handle this on her own? Hansen was used to answering calls and responded professionally. "Was your son hurt?" he asked.

The woman said he was fine and pointed her son out. Oblivious to his mother's agitation, the blond boy played gleefully with other partygoers. The woman continued, telling us that the boy who had hit her son was gone but that his sister was still there. Both children were unsupervised, and the woman did not want the responsibility of looking after them.

I looked at the little girl who was the alleged stick thrower's sister. She was about four years old and appeared to be Latina. She had chocolate brown skin and dark 
brown hair pulled back in a high, tight braided ponytail. Officer Hansen walked toward her with his hand outstretched and asked her to take us to her mother. The little girl's shoulders slumped and her face fell. She looked up at the officer's outstretched hand and reluctantly extended her own, allowing the officer to hold on to it.

She led us across an expansive green lawn toward the apartment complex across the street. The closer we got to her apartment, the more upset she became. Tears streamed down her face. Twice she tripped over her own feet and was kept upright by Officer Hansen, who was still holding her hand. Seeing her distress, he tried to reassure her.

"You're not in trouble," he said lightly, with a smile. This did not assuage her fears.

We climbed up three flights of stairs and arrived at a door. The officer knocked loudly, and several moments later a young woman in her early twenties answered the door. She was holding a sleeping infant who was wrapped tightly in a thin baby blue blanket.

The little girl flung herself at her mother, wrapping her arms around her legs and sobbing and hiccupping loudly.

"What happened?" the mother asked her daughter in Spanish, in an alarmed voice. She tried to pry the girl from her legs to get a look at her but was unsuccessful.

The officer looked at me and nodded me forward. I took the cue and explained, in Spanish, that a mother at a birthday party had called us because of a squabble between their sons. She nodded while patting her daughter on the shoulder, telling us that she couldn't leave because she had just had a baby and he was too young to go outside. I suggested that her son stay away from the woman and her child, because the woman had been very upset. She nodded in agreement, sharing that the little boy had played roughly with her son in the past.

"ID?" the officer asked, pointing at her and placing his hands in the shape of an identification card. The woman nodded and turned to a back room to retrieve her purse. She returned with a shoulder bag and rummaged through it, finally producing a Mexican consular identification card. The officer grabbed the card and quickly began filling out an incident report on his clipboard.

As the woman waited, she turned her attention to her daughter, whose sobs had become the occasional sniffle. "There, there, there, don't cry anymore," the young mother told her daughter. Looking down at her with a reassuring smile, she said, "Everything's going to be fine!" The girl seemed unconvinced, and she hovered around her mother's legs until we left.

The officer handed the woman a copy of the incident report and told her to have a nice day. The woman nodded and thanked us, and we pounded down the stairs. Hansen was anxious to get back to patrol.

Sociologist Joanna Dreby has found that children in Mexican immigrant households worry about family stability and the consequences of "illegality." Unable to 
distinguish between police and immigration enforcement authorities, both parents and children believe that the police may separate their families. Through their parents, children learn that they need to be cautious when police are around. Even the threat of deportability has negative effects on children's well-being and identity. ${ }^{27}$

During this interaction, I saw a little girl who had learned through experience that the police represented danger. However, as we got back in the car, it was clear that Officer Hansen did not arrive at the same conclusion. Hansen remarked on the little girl's demeanor, but he was puzzled by it. According to Hansen, the little girl's behavior bothered him because she had not been taught that police were the "good guys." He believed children should respect, or even idolize, the police. He did not understand why she, or any child, might regard the police with such apprehension.

"Yeah, it's weird," I agreed, mimicking Hansen's bewilderment, even though I did not think it was weird at all.

\section{COMMUNITY RELATIONS IN}

\section{AN ERA OF PROACTIVE POLICING}

There is a remarkable contrast between the police department's perception of its activities vis-à-vis Latino residents, and Latino residents' perception of those activities. Police department administrators pointed out that the department devoted considerable resources to improving their relationship with Latino residents. Police officials knew that they are not perfect, but they believed they work hard to demonstrate a sincere commitment to serving Latino immigrant residents. As this chapter demonstrates, the MNPD devoted time and attention to improving the department's standing in the Latino immigrant community. Indeed, the El Protector program largely exemplifies the processes of bureaucratic incorporation described by Jones-Correa. However, while the MNPD's El Protector program and its numerous activities represented a genuine effort to make inroads with Latino residents, the program's dubious origins and the department's emphasis on proactive policing raise doubts about the program's effectiveness and sincerity. Police saw Latino immigrants as residents who were worthy of protection, but they did not care to see how their own practices contributed to immigrants' precarity. Patrol officers, who were inculcated with the wisdom of proactive policing, were similarly indifferent to Latino immigrants' concerns.

These days, virtually all American police departments invest energy and resources to demonstrate that they engage in "community policing." ${ }^{28}$ Indeed, departments invoke the idea of community policing as a way to claim legitimacy and to imply that residents endorse their approach. ${ }^{29}$ The department similarly touted the El Protector program as an example of "community policing." While 
there is some disagreement about what policing practices constitute community policing, scholars agree that it consists of partnerships between police and the citizenry to solve community problems. ${ }^{30}$ Thus, although the El Protector program incorporated some community policing philosophies, such as listening to residents' concerns and trying to improve police relations in the community, ultimately the El Protector program served primarily to educate Latino immigrants, not to incorporate them as partners to solve problems. The goals and philosophy of the El Protector program were not integrated into the department writ large. Latino residents' most pressing concerns related to the behavior of patrol officers. While Officers Iglesias and Moreno attended events to spread the message that the department could be trusted, patrol officers were searching cars, asking residents for IDs, and serving warrants. 